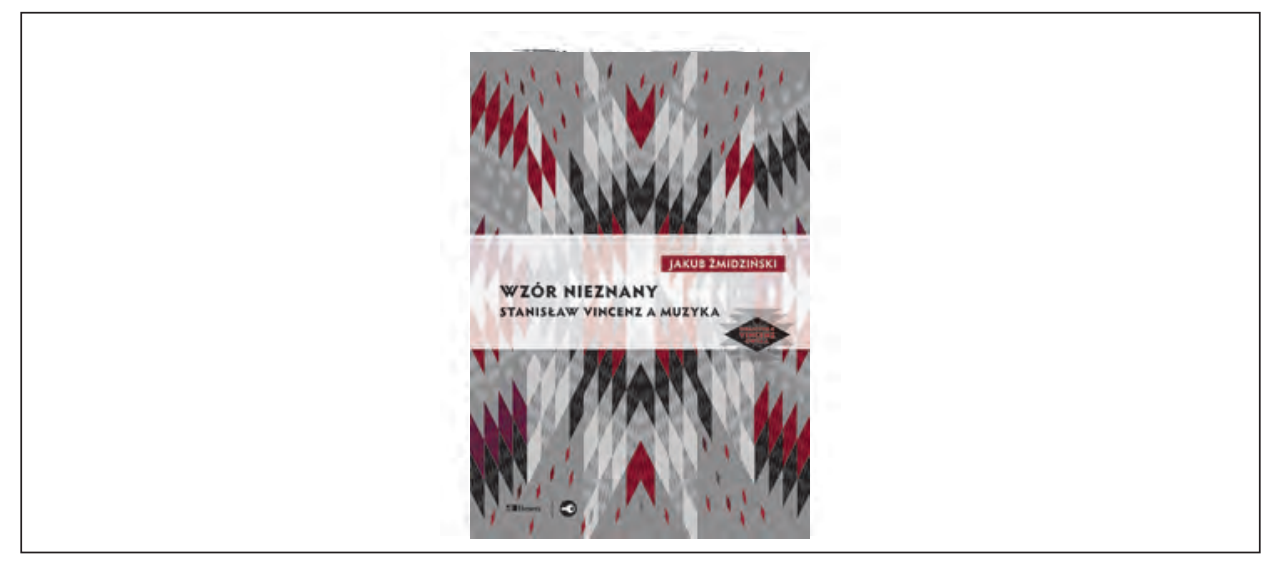

\title{
Stanisław Vincenz i „piosnki anielskie”
}

https://doi.org/10.19195/2084-4107.13.29

[rec.:] Jakub Żmidziński, Wzór nieznany. Stanisław Vincenz a muzyka, „Biblioteka Vincenzowska", red. Jan A. Choroszy, t. 4, a linea, Wrocław 2018, ss. 365 .

\section{Stanisław Vincenz and "angels' songs"}

Słowa-klucze: Stanisław Vincenz, Huculszczyzna, muzyka w literaturze, folklor muzyczny

Keywords: Stanisław Vincenz, Hutsul Region, music in literature, musical folklore

Przytaczając w Listach z nieba (Na wysokiej połoninie) oryginalny fragment huculskiej śpiewanki o aniołach, Stanisław Vincenz skomentował fenomen muzyki towarzyszącej mieszkańcom Huculszczyzny: „To raczej piosnka z nieba, nie list, to zaproszenie aniołów i ich śpiewanka do tańca". Przywołana deklaracja interioryzuje duchowy charakter całej twórczości autora tetralogii huculskiej. Uświadamia to w pełni lektura monografii Jakuba Żmidzińskiego Wzór nieznany. Stanisław Vincenz a muzyka (2018). Ta niebanalna publikacja jest próbą nowatorskiej interpretacji twórczości Vincenza przez pryzmat aspektów muzykologicznych, a przy okazji ważny przyczynek zarówno do badań nad dokonaniami literackimi Stanisława Vincenza, jak i do rozważań na temat muzyki i muzyczności w literaturze XX wieku.

Żmidziński - autor obszernej monografii o Pieninach (Pieniny w literaturze polskiej, Poznań 2010), literaturoznawca, eseista i poeta — podjął nadzwyczajne

1 S. Vincenz, Na wysokiej połoninie. Prawda starowieku. Obrazy, dumy i gawędy z Wierzchowiny Huculskiej, Warszawa 1979, s. 531. 
zadanie intelektualne i analizując dzieło Vincenza (Na wysokiej połoninie), wyznaczył w nim rozmaite perspektywy funkcjonowania muzyki, uzasadniając, że dzieło to stanowi całościowe opus magnum, znakomicie komunikujące istotę muzycznej kosmogonii, a zarazem uznał je za jedną z najważniejszych wypowiedzi na temat „muzyki wszechświata” w literaturze polskiej XX wieku.

Wskazując obecność tradycji literackiej w tetralogii Vincenza (między innymi Homera, Sokratesa, Platona, Dantego) i wnikliwie charakteryzując rzeczywistość przedstawioną, autor nie tylko uzasadnia rolę zaświatów, lecz w ich obrębie akcentuje także ważną sferę „dantejską" (rajską), konkludując, że Na wysokiej połoninie

jest traktatem filozoficznym i duchowym w literackiej szacie, utkanej w poetyce mitu, traktatem o kilku ważnych zagadnieniach nieba i ziemi oraz tajemnicy człowieka zasłyszanej w konkretnym miejscu, gdzie zbiegają się drogi z rzeczywistych centrów świata. Poznał ją autor wśród Hucułów i od Hucułów zachowujących z epoki dawności to, co istotne. (s. 327)

Wedle Żmidzińskiego obecność mitu umożliwiła zatem kreację symbolicznych, wyjątkowych obrazów, „wielowymiarowo” nacechowanych muzyką. Pojawia się przy tym ważna konstatacja, że w tetralogii Vincenza realizują się trzy płaszczyzny muzyczności literatury. Na poziom brzmieniowy tekstu (rytmizacji, form narracyjnych) najpełniej oddziaływały dzieła Homera, dzięki czemu udało się Vincenzowi uzyskać bogactwo żywego słowa. Na poziomie tematycznym tetralogia Vincenza w sposób niezwykle plastyczny i akustyczny obrazuje świat przedstawiony, co ujawnia się zwłaszcza w opisach przyrody, ale nie tylko. Autor udowadnia, że całość narracji emanuje głosami ludowych huculskich instrumentów: „trombity”, skrzypiec, cymbałów, dud i fłojery, której poświęcony został osobny rozdział. Jak twierdzi Żmidziński:

Muzyka instrumentalna często splata się ze śpiewem i tańcem, tworząc zjawisko, które za tradycją grecką można nazwać choreą huculską obrzędowym celebrowaniem świąt, kiedy trzy sztuki: muzyka, taniec i poezja nieustannie dialogują i współdziałają, tworząc oryginalną strukturę. (s. 327)

$\mathrm{Na}$ poziomie kompozycyjnym autor $\mathrm{w}$ różnych partiach rozważań dostrzega korelacje literackości ukształtowanej na wzór form muzycznych. Co znamienne, Żmidziński podkreśla, że w twórczości Vincenza można dostrzec ślady doświadczenia mistycznego (autopsyjnie niegdyś doznanego przez autora Na wysokiej poloninie) o charakterze muzycznym, dlatego obrazy literackie są nie tylko konsekwencjami gry wyobraźni, erudycji i tropów kulturowych, lecz mają swe źródło w autentycznym doświadczeniu mistycznym. Ujawnia się ono w audiosferze emanującej grą kosmogonii (między innymi grą gwiazd i śpiewem aniołów), przy czym nobilitowane są odgłosy rzeczywistości ludzkiej, do której 
należy również muzyka natury, prowadząca ku zjawisku polifonii. $\mathrm{Na}$ tym obszarze Żmidziński również formułuje istotne wnioski, sugerując, że fascynacja polifonią Bacha zainspirowała Vincenza do wymodelowania dzieła na wzór fugi polifonicznej. Co prawda, na początku XX wieku muzykolodzy dyskutowali nad kryzysem polifonii, bardziej predestynując formę wyrazu. Można ów fakt odnieść do modnej ówcześnie tendencji artystycznej „wyrażania niewyrażalnego” jako charakterystycznej cechy symbolizmu. Warto jednak sięgnąć w głąb historii estetyki muzycznej, albowiem w dziedzinie muzyki to romantycy jako pierwsi wychodzili z założenia, że „wyrazić niewyrażalne” oznacza zainspirować wizję wieczności, zwerbalizować emocjonalny stan duszy. Język muzyki (forma wyrazu) zyskał znaczenie uprzywilejowanego, bo oddającego siłę emocji, afektowanych doznań, inspirujących przeżyć - to domena nie tylko twórczości romantyków, ale muzyki w ogóle. Tetralogię Vincenza Żmidziński traktuje jak literacką fugę skomponowaną wokół wielkiego tematu „grania światowego”, albowiem — jak udowadnia autor - tetralogia huculska Vincenza jest przede wszystkim pieśnią, upodobnioną do Homerowskiej Odysei i Boskiej komedii Dantego.

Niewątpliwie najciekawszym aspektem interpretacji Żmidzińskiego jest próba definicji ,światowego grania”, przenikającego pisarstwo Vincenza. W tym aspekcie badacz również nawiązuje do definicji harmonii odwzorowującej równowagę całej kosmogonii, czyli do średniowiecznych traktatów muzycznych, między innymi do traktatu Boecjusza, który jako pierwszy przeprowadził trójpodział muzyki, wyróżniając na podstawie jej struktury harmonicznej trzy podstawowe wyznaczniki: musica mundana, musica humana i musica instrumentalis, przy czym za jedyną prawdziwą wyrazicielkę harmonii muzycznej Boecjusz uważał musica mundana - harmonię świata, uporządkowany ruch elementów składający się na materialny wszechświat. Obecność tego porządku Żmudziński analizuje w różnorakich kontekstach i w kilku partiach monografii, sugerując, że w twórczości Vincenza występuje oryginalna i bardzo specyficzna filozofia muzyki (zakorzeniona w tradycji filozoficznej i literackiej) oraz że tę Vincenzowską filozofię muzyki prowokuje filozofia przestrzeni, gdyż u analizowanego twórcy wymiar przestrzenny łączy się z wymiarem czasowym, a wizualny z akustycznym, natomiast forma literacka powiązana jest $\mathrm{z}$ muzycznością. Celem przewodnim tych rozważań stało się uzasadnienie tezy, że muzyka jest „metatekstem”, „metarytmem”, „metamuzyką". Opisując, jak brzmi huculska symfonia, huculska pieśń, muzyka natury, emanujące z materii literackiej, Żmidziński wskazuje nawiązania do tradycji muzyki klasycznej (na przykład do Mozarta), do muzyki folkloru (na przykład romskiego), do tradycji form muzycznych (na przykład gatunku marszowego). Wskazuje również obecność tak zwanej obrzędowej syntezy sztuk, charakteryzując Vincenzowską koncepcję święta i obrzędu. W pejzażu akustycznym $\mathrm{Na}$ wysokiej połoninie ważną rolę odgrywają oddźwięki natury (muzyka wiatru, lasu i innych żywiołów kosmogonicznych). Nad bogatymi pod względem artystycznym, sensualistycznymi opisami pejzażu dominują śpiewanki aniołów metafizyka o proweniencji biblijno-ludowej: 
Nad wszystkim jaśniały w pogodnej toni rzęsiste gwiazdy jesiennego nieba. Wznosiły się powoli ku szczytowi nieba. Siedmiu Archaniołów - Plejady święte. Świetlistym rojem błogosławiły westchnieniom pasterzy ${ }^{2}$.

Monografia Żmidzińskiego — badacza doświadczonego wieloletnimi studiami nad twórczością Stanisława Vincenza - jest niezwykle wartościowym opracowaniem naukowym, ciekawą interpretacją tematu, a także lekturą wyjątkowo refleksyjną, wyrastającą z bogatego fundamentu erudycyjnego (filozoficznego, literackiego i muzycznego). Książka ukazała się w serii wydawniczej „Biblioteki Vincenzowskiej" (zainicjowanej przez Jana A. Choroszego), w której publikowane są dokonania naukowe oraz materiały źródłowe do badań nad rozmaitymi aspektami twórczości autora $\mathrm{Na}$ wysokiej połoninie. Nie ulega wątpliwości, że to kolejne wielkie osiągnięcie zarówno całej serii, jak i samego autora.

Matgorzata Łoboz

ORCID: 0000-0002-0705-8219

Uniwersytet Wrocławski malgorzata.loboz@uwr.edu.pl

${ }^{2}$ Ibidem, s. 532. 